University of Michigan Law School

University of Michigan Law School Scholarship Repository

Articles

Faculty Scholarship

1916

\title{
When Is a Preferential Transfer Required to Be Recorded?
}

Evans Holbrook

University of Michigan Law School

Available at: https://repository.law.umich.edu/articles/666

Follow this and additional works at: https://repository.law.umich.edu/articles

Part of the Bankruptcy Law Commons, and the Supreme Court of the United States Commons

\section{Recommended Citation}

Holbrook, Evans (1907-1932). "When Is a Preferential Transfer Required to Be Recorded?" Mich. L. Rev. 14 (1916): 578-82.

This Response or Comment is brought to you for free and open access by the Faculty Scholarship at University of Michigan Law School Scholarship Repository. It has been accepted for inclusion in Articles by an authorized administrator of University of Michigan Law School Scholarship Repository. For more information, please contact mlaw.repository@umich.edu. 
When is a Prefeirentiat, Transter "Required" to be Recorded?-In the Tecent case of Carey v. Donohne, 36 Sup. Ct. 386 , the Supreme Court of the United States has paśsed on a question that has for years been vexing the Circuit Courts of Appeals, namely: When is the recording of a preferential transfer "required" under $\$ 60$ of the Bankruptcy Act of 1898 as amended in 1903 and 1910. $\$ 60 a$ (as amended in I903) defines a preference as a transaction by which property of an insolvent debtor is transferred; within four months before his bankruptcy, in such a way that the debt owing to one of his creditors will be paid in a greater percentage than the debts owing to other creditors, and adds: "Where the preference consists in a transfer, such period of four months shall not expire until four months after the date of the recording or registering of the transfer, if by law such recording or registering is required." $\S 60 \mathrm{~b}$ (as amended in 1903 and in 19ro) provides that the debtor's trustee in bankruptcy may recover property so transferred preferentially, if the preferred creditor had "reasonable cause to believe" that a preference was to be effected "at the time of the transfer $* * *$ or of the recording or registering of the transfer if by law recording or registering thereof is required," such time being within four months before bankruptcy.

Concretely stated, the question in Carey v. Donohue was as follows: a deed was given by an insolvent debtor on August 6 to a creditor who then "had reasonable course to believe that such transfer to him if made would effect a preference, being given in payment of an antecedent debt;" the deed was recorded on November I5; on January 3 a petition was filed to declare the debtor a bankrupt, and on January 24 he was adjudicated bankrupt; his trustee in bankruptcy then sued the preferred creditor to recover the value of the property transferred.

Thus the familiar situation is presented of a transfer which clearly contains every element of a voidable preference except the element of time--that 
element being doubtful. The deed was executed and delivered more than four months before bankruptcy, it was recorded within four months of bankruptcy; if the period of four months runs from the date of the transfer, the trustee in bankruptcy cannot recover the property or its value from the preferred creditor; if that period runs from the date of the record, he can. If by law the recording of the instrument was required, the date of record governs. The law which governed the matter of recording was $\$ 8543$ of the Ohio Code, which provided that deeds of lands, until recorded, were to be "deemed fraudulent so far as relates to a subsequent bona fide purchaser having, at the time of the purchase, no knowledge of the existence of such former deed or instrument." The District Court and the Circuit Court of Appeals, following the rule laid down by the latter in Loeser v. Savings Deposit Bank \& Trust Co., 148 Fed. 975,78 C. C A. 597, I8 L. R. A. N. S. I233, held that the recording act's provision in the interest of bona fide purchasers constituted a "requirement" of recording under $\$ 60$ of the Bankruptcy Act, and accordingly permitted the trustee in bankruptcy to recover the value of the property from the preferred creditor and grantee.

The Supreme Court, reversing the decisions below, took the view that the provision of the Act as to recording was meant only "to embrace those cases in which recording was necessary in order to make the transfer valid as against those concerned in the distribution of the insolvent estate; that is, as against creditors, including those whose position the trustee was entitled to take;" that a requirement of recording in the interest of subsequent purchasers was therefore not such a requirement as was intended by the Act, that the transfer was according completely effective (so far as proceedings in bankruptcy are concerned) at the date of its execution and delivery, and that the trustee in bankruptcy was barred by the lapse of four months from that date.

In the words of Justice HugHes, who delivers the opinion of the Supreme Court, "With respect to the construction of the clause in question, there has been diversity of opinion in the circuit courts of appeals. In the Sixth, Seventh, and Eighth Circuits, the view has been taken that the word 'required' refers 'to the character of the instrument giving the preference' without regard to the persons in whose favor the requirement is imposed; that is, if the transfer is required to be recorded as to anyone, the trustee may recover if it has not been recordea morc than four months before the filing of the petition in bankruptcy. See Loeser v. Savings Deposit Bank \& Trust Co., (C. C. A. Sixth), I48 Fed. 975, 979, (followed by the decision in the present case); In re Beckhaus, (C. C. A. Seventh), 177 Fed. I4I (see In re Sturtevant, (C. .C. A. Seventh), I88 Fed. I96); First National Bank v. Connett, (C. C. A. Eighth), r42 Fed. 33, 36; Mattley v. Geisler, (C. C. A. Eighth), 187 Fed. 970, -971. A different conclusion has been reached in the Second, Fifth and Ninth Circuits. See In re Boyd, (C. C. A. Second), 212 Fed. 774; Meyer Drug Co. v. Pipkin Drug Co., (C. C. A. Fifth), I36 Fed. 396; In re McIntosh, (C. C. A. Ninth), I50 Fed. 546; also In re Hunt, (D. C., N. Y.), I39 Fed. 283."

In addition to the authorities cited by Justice HUGHES, this provision of the Act has been passed on and referred to in many other cases. In the Sixth Circuit, Loeser v. Trust Co., supra, has been followed in Ragan v. 
Donovan, I89 Fed. 138; and In re Donnelly, 193 Fed. 755; in the Seventh Circuit, In re Beckhans, supra, has been followed on this point by In-re Caslon Press, 229. Fed. $\mathrm{I33}$; in the Eighth Circuit First National Bank v. Connett and Mattley v. Geisler, supra, have been followed in McElwain v. Hardesty, 169 Fed. 31, 94 C. C. A. 399; People's Bank v. Gleason, 178 Fed. 1004, I0I C. C. A. 663; Willians v. German Trust Co., 219 Fed. 507, I35 C. C. A. 257; Smith v. Orr, 224 Fed. 7I, 139 C. C. A. 5I7; In re Bunch Commission Co., 225 Fed. 243; and Sieg v. Greene, 225 Fed. 955, - C. C. A. -. The Supreme Court of South Dakota has also adopted this view in Bozoler v. First National Bank, 2I S. Dak. 449, in which the court refers to, quotes from, and follows Loeser v. Trust Co., supra, without citing it. The same result was. reached in the Second Circuit by Judge ARCHBALD of the District Court for the Middle District of Pennsylvania in English v. Ross, I40 Fed. 630, though he reached it by holding that the provision in $\S 60$ should be construed as reading "required or permitted" as it reads in $\$ 3 \mathrm{~b}$. On the other hand the cases cited by. Justice HuGHES as coming to a "different conclusion" have also. been followed, though perhaps to a less degree. In Geltman v. Lippert, I57 N. Y. Supp. 867, the Boyd and Hunt cases were followed; the-Meyer Drug Company case was followed in the Fifth Circuit in Keeble v. Deere Plow Co., rgo Fed. rorg, III C. C. A. 668; In re Jacobson \& Perrill, 200 Fed. 812; Andersoñ v. Chenault, 208 Fed. 400 , 125 C. C. A. 616; In re Roberts, 227 Fed. 177; and Martin v. Commercial Bank, 228 Fed. 651, - C. C. A. -. Many other cases have discussed this provision incidentally, but generally they have gone off on some other phase of the matter, and it is believed that the cases cited above are fairly representative of the state of the law as it was before the Supreme Court's decision of the principal case.

What change has been made by Carey v. Donolnue? The general viè is that the Circuit Courts of Appeals of the Sixth, Seventh, and Eighth Circuits have been overruled, and that the Circuit Courts of Appeals of the Second, Fifth, and Ninth Circuits have been upheld. It is obviously true that the Supreme Court. has disapproved the basis of decision followed in the first group of courts,' namely: that a requirement for any purpose constitutes a requirement under $\$ 60$; but it is far from true that the cases heretofore decided in those courts would be differently decided under the rule just laid down ir Carcy v. Donohue. And apparently the Supreme Court's new ruls would not in every case produce the same effect as has been produced by the decisions in the second group of Circuit Courts of Appeals. For instance the court in Meyer Drug Co. v. Pipkin Drug Co., supra, held that there was no "requirement" of record in that case because an unrecorded chattel mortgage was valid under the law of Texas as against the mortgagor and his general creditors (in whose shoes stood the trustee in bankruptcy) though void against lien creditors. The later cases in this Circuit (cited above) seem to take the view that the enlargement of the trustee's powers by the I9I0 amendment of $\S 47 \mathrm{a}$ (2) makes no difference in this respect, perhaps because those powers do not become effective until the filing of a petition. The Supreme Court, however, seems to take the position that recording is "required" under $\S 60$ if it is required "for the protection of-creditors,- - the persons interested 
in the bankrupt estate, and in whose behalf, or in whose place, the trustee is entitled to act." In another part of the opinion the requirement is referred to as one necessary to make the transfer valid "as against creditors, including those whose position the trustee was entitled to take." And in stating the question before it for decision, the court uses the following language with reference to the Ohio law: "We assume that there was no requirement that this conveyance should be recorded in order to give it validity as against any creditor of the bankrupt, whether a general creditor, or a lien creditor, or a judgment creditor with execution returned unsatisfied; that is, as against any class of persons represented by the trustee or with whose 'rights, remedies, and powers' he was to be deemed to be vested. Bankruptcy Act, §47a."This language seems to indicate pretty clearly that if the local law requires recording as against any of the classes of persons referred to in $\$ 47 \mathrm{a}$ (2) there is a "requirement" under $\$ 60$. Under $\$ 47$ a (2) the trustee is given the "rights, remedies, and powers of a creditor holding a lien by legal or equitable proceedings" on property in the custody or coming into the custody of the bankruptcy court; as to property not in such custody, he has the "rights, remedies, and powers of a judgment creditor holding an execution duly returned unsatisfied." The Supreme Court, in the language last above quoted from its opinion, seems to indicate, without regard to any distinction as to the two classes of property referred to in $\$ 47 a(2)$, that if the local law requires recording as against any of the classes of creditors referred to in that section, recording is required under $\$ 60$. If this interpretation of the holding is correct, Carey v. Donohue -would require a reversal of cases (arising since I910) like the Meyer Drug Co. case and the other cases in the Fifth Circuit cited above, for it seems clear that in those cases recording was required as against lien creditors. In the cases cited from the Second Circuit, the question arose under a New York recording act which (like the Ohio act in Carey v. Donohue) made an unrecorded conveyance void only as to subsequent purchasers; the decisions in those cases, therefore, square exactly with the Supreme Court's ruling. The same result would apparently follow under the Cailifornia statute which raised the question in In re McIntosh, supra.

It is singular, however, that practically all of the cases decided under the repudated rule of the Sixth, Seventh, and Eighth Circuits would be decided exactly the same under the rule laid down in Carey v. Donohue. In all but three of the cases cited above from those circuits, the instruments of transfer were required to be recorded to be valid as against creditors, and would therefore, even under the rule of Carey v. Donohue, be held to come within the provisions of $\S 60$ as to record. We are thus confronted with this rather paradoxical situation: if the cases decided under the rule heretofore followed in the Second, Fifth and Ninth Circuits (which rule the Supreme Court is generally, but erroneously, supposed to have approved) were now to arise and be presented to the Supreme Court for review, a majority of them would be reversed; if the cases decided under the rule heretofore followed in the Sixth, Seventh, and Eighth Circuits (which rule the Supreme Court has expressly overruled) nearly all of them would be affirmed. It is to be hoped that a case 
like the Meyer Drig Co. case may soon be presented to the Supreme Court, so that its view on that particular phase of the question may be expressed instead of inferred.

E. H. 